\title{
Carbohydrate restriction and dietary cholesterol modulate the expression of HMG-CoA reductase and the LDL receptor in mononuclear cells from adult men
}

\author{
Gisella Mutungi ${ }^{1}$, Moises Torres-Gonzalez ${ }^{1}$, Mary M McGrane ${ }^{1}$, Jeff S Volek ${ }^{2}$ \\ and Maria Luz Fernandez*1
}

Address: ${ }^{1}$ Department of Nutritional Sciences, University of Connecticut, Storrs, CT, 06269 USA and ${ }^{2}$ Department of Kinesiology, University of Connecticut, Storrs, CT 06269, USA

Email: Gisella Mutungi - gmgm218@hotmail.com; Moises Torres-Gonzalez - motogo3@hotmail.com;

Mary M McGrane - mary.mcgrane@uconn.edu; Jeff S Volek - jeff.volek@uconn.edu; Maria Luz Fernandez* - maria-luz.fernandez@uconn.edu

* Corresponding author

Published: 28 November 2007

Lipids in Health and Disease 2007, 6:34 doi:I0.1 I86/I476-5IIX-6-34

This article is available from: http://www.lipidworld.com/content/6/I/34

(c) 2007 Mutungi et al; licensee BioMed Central Ltd.

This is an Open Access article distributed under the terms of the Creative Commons Attribution License (http://creativecommons.org/licenses/by/2.0), which permits unrestricted use, distribution, and reproduction in any medium, provided the original work is properly cited.

\begin{abstract}
The liver is responsible for controlling cholesterol homeostasis in the body. HMG-CoA reductase and the LDL receptor (LDL-r) are involved in this regulation and are also ubiquitously expressed in all major tissues. We have previously shown in guinea pigs that there is a correlation in gene expression of HMG-CoA reductase and the LDL-r between liver and mononuclear cells. The present study evaluated human mononuclear cells as a surrogate for hepatic expression of these genes. The purpose was to evaluate the effect of dietary carbohydrate restriction with low and high cholesterol content on HMG-CoA reductase and LDL-r mRNA expression in mononuclear cells. All subjects were counseled to consume a carbohydrate restricted diet with $10-15 \%$ energy from carbohydrate, $30-35 \%$ energy from protein and $55-60 \%$ energy from fat. Subjects were randomly assigned to either EGG $(640 \mathrm{mg} / \mathrm{d}$ additional dietary cholesterol) or SUB groups [equivalent amount of egg substitute ( 0 dietary cholesterol contributions) per day] for 12 weeks. At the end of the intervention, there were no changes in plasma total or LDL cholesterol (LDL-C) compared to baseline $(P>0.10)$ or differences in plasma total or LDL-C between groups. The mRNA abundance for HMG-CoA reductase and LDL-r were measured in mononuclear cells using real time PCR. The EGG group showed a significant decrease in HMG-CoA reductase mRNA (I.98 \pm 1.26 to $1.32 \pm 0.92$ arbitrary units $P<0.05$ ) while an increase was observed for the SUB group $(I .13 \pm 0.52$ to $I .69 \pm 1.6 \mathrm{I}$ arbitrary units $P<0.05)$. Additionally, the LDL-r mRNA abundance was decreased in the EGG group $(1.72 \pm 0.69$ to $1.24 \pm 0.55$ arbitrary units $P<0.05)$ and significantly increased in the SUB group $(1.00 \pm 0.60$ to $1.67 \pm 1.94$ arbitrary units $P<0.05)$. The findings indicate that dietary cholesterol during a weight loss intervention alters the expression of genes regulating cholesterol homeostasis.
\end{abstract}

\section{Background}

Cholesterol is an important biological molecule that plays a role in membrane structure and it is a precursor for the synthesis of steroid hormones and bile acids [1,2]. It is also a major player in the lipid rafts which have a vital role in cell signaling and protein sorting on the membrane sur- 
face [3-5]. Mammalian cells produce their own cholesterol and receive cholesterol by uptake from lipoproteins [5]. Regulation of synthesis, influx and efflux keeps cellular cholesterol levels precisely controlled [5]. The synthesis of cholesterol is regulated by the activity of the microsomal enzyme 3-hydroxy-3 methylglutaryl coenzyme A (HMG-CoA) reductase, and this is determined by both the amount of protein present and the degree of activation of the enzyme (dephosphorylation) [6,7]. One of the main mechanisms of cholesterol uptake by the cells is through the LDL receptor (LDL-r). The LDL-r synthesis is activated by low concentrations of cellular free cholesterol [8]. Animal data suggest that cholesterol synthesis and cholesterol uptake by the LDL-r may work independently, and that LDL uptake by the receptor is a secondary compensatory mechanism after cholesterol synthesis [9]. Cholesterol homeostasis is the mechanism of ensuring appropriate physiological cholesterol levels $[5,10]$. First demonstrated in vitro, the LDL-r gene is down regulated by higher intracellular cholesterol $[10,11]$ and so is HMGCoA reductase [12]. Dietary macronutrients have a major impact on plasma lipids, and both LDL-r and HMG-CoA reductase have a central role in lipid metabolism [13]. Therefore we determined the mRNA expression of these two genes in response to two levels of dietary cholesterol in the context of a low carbohydrate intake. We demonstrated that increased intake of cholesterol affects mRNA expression of both HMG-CoA reductase and LDL-r.

\section{Methods \\ Diets}

These were free living subjects who were not provided with any other foods apart from either eggs or eggs substitute to consume as part of a low carbohydrate diet. No restrictions were given towards energy intake. Subjects received individual and personalized dietary counseling from Registered Dietitians prior to the dietary intervention. Detailed dietary booklets, specific to each dietary treatment, were provided outlining dietary goals, lists of appropriate foods, recipes, sample meal plans, and food record log sheets. Subjects received weekly follow-up counseling during which body mass was measured, compliance was assessed, and further dietetic education was provided. A three-day weighed food records was obtained at baseline to assess habitual nutrient intake, and a fiveday records were completed during weeks 1,6 , and 12 of the intervention.

Subjects were given specific instructions on how to follow a carbohydrate restricted diet (CRD), as previously reported from our lab [14]. Subjects were asked to maintain their normal routine of physical activities during the course of this study.

\section{Mononuclear cell Isolation}

Whole blood was used to isolate mononuclear cells following method by Boyum [15]. In this method $20 \mathrm{~mL}$ blood was diluted with $10 \mathrm{~mL}$ HBSS (Sigma-Aldrich) that did not contain either $\mathrm{Ca}^{2+}$ or $\mathrm{Mg}^{2+}$. Then this diluted solution was carefully layered over $10 \mathrm{~mL}$ of Histopaque 1077 (Sigma-Aldrich), and centrifuged at $500 \times \mathrm{g}$ for 30 minutes (Rotanta $460 \mathrm{R}$ ). The mononuclear cell interface was removed and washed with HBSS and centrifuged at $600 \times \mathrm{g}$ for 10 minutes twice. The cell pellet was resuspended in $200 \mu \mathrm{L}$ Tris buffer $(150 \mathrm{mmol} / \mathrm{L} \mathrm{NaCl}, 10$ $\mathrm{mmol} / \mathrm{L}$ Tris, $1 \mathrm{mmol} / \mathrm{L} \mathrm{CaCl} 2, \mathrm{pH} 7.4$ ), and the sample was stored at $-80^{\circ} \mathrm{C}$.

\section{RNA extraction and purification}

Total RNA was extracted from mononuclear cells using a slightly modification of the method of Chomczynski and Sacchi [16]. TRIzol reagents were used as per manufacturer's guidelines. The integrity of the extracted RNA was checked by electrophoresis on a $1 \%$ agarose gel. The DNAfree kit was used to remove trace contaminating genomic DNA following the manufacturer's instruction (Bio-Rad). RNA was extracted by precipitation using 2.5 volumes of $100 \%$ ethanol and 0.1 volume of $3 \mathrm{~mol} / \mathrm{L}$ sodium acetate at $\mathrm{pH}$ 5.2. The RNA pellet was washed with 70\% ethanol and dissolved in diethyl pyrocarbonate-treated water. cDNA synthesis was done using iScript cDNA synthesis kit as per manufacturer's instructions (Bio-Rad).

\section{Real-time PCR}

LightCyler Probe Design software 2.0 (Roche Diagnostics) was used to design primers for the target genes, HMG-CoA reductase, LDL-r and the reference gene glyceraldehyde-3phosphate dehydrogenase (GAPDH) [17].

Using the LightCycler FastStart DNA Master plus SYBR Greeen I (Roche Diagnostics) real-time Polymerase Chain Reaction (PCR) was performed in duplicate using the LightCycler 2.0. A melting curve was obtained after amplification, to determine the optimal PCR conditions. By analyzing the fluorescence curves and detecting the crossing point of samples using LightCycler software 4.0 (Roche Diagnostics) quantification of mRNA was done.

\section{Plasma Lipids}

Total cholesterol (TC) and HDL cholesterol (HDL-C) were determined by enzymatic methods. LDL Cholesterol (LDL-C) was calculated by the Friedwal equation after measurement of plasma total cholesterol, triglycerides and HDL-C as previously reported [18].

\section{Statistical analysis}

Data was analyzed using Repeated Measures ANOVA with time being the repeated measure and EGG versus SUB the 
between subjects factor. Data are presented as means \pm SD. Differences of $P<0.05$ were considered significant.

\section{Results}

Plasma TC was not affected by diet or over time. Values were $198.3 \pm 42.1 \mathrm{mg} / \mathrm{dL}$ at baseline and $202.2 \pm 41.8 \mathrm{mg} /$ $\mathrm{dL}$ at $12 \mathrm{wk}$ for the EGG group and $188.3 \pm 33.7$ and 187.3 \pm 39.5 at baseline and $12 \mathrm{wk}$ respectively for the SUB group. In spite of the greater consumption of dietary cholesterol in the EGG group ( $877 \mathrm{mg} / \mathrm{d})$ at wk 12 compared to the SUB group $(277 \mathrm{mg} / \mathrm{d})$, there were no increases in LDL-C between baseline and $12 \mathrm{wk}$ or differences in LDL$\mathrm{C}$ between the EGG and the SUB groups. Values were $127.5 \pm 42.2 \mathrm{mg} / \mathrm{dL}$ at baseline and $144.3 \pm 45.1 \mathrm{mg} / \mathrm{dL}$ after $12 \mathrm{wk}$ for the EGG group while values for the SUB group were $110.8 \pm 34.5 \mathrm{mg} / \mathrm{dL}$ for baseline and $121.5 \pm$ $42.2 \mathrm{mg} / \mathrm{dL}$ after $12 \mathrm{wk}(\mathrm{P}>0.1)$. In contrast, HDL-C was significantly increased only in the EGG group from $47.6 \pm$ $15.1 \mathrm{mg} / \mathrm{dL}$ at baseline to $57.1 \pm 15.1 \mathrm{mg} / \mathrm{dL}$ at $12 \mathrm{wk}$ while there were no changes in HDL-C in subjects from the SUB group $(50.0 \pm 9.7 \mathrm{mg} / \mathrm{dL}$ at baseline and $48.8 \pm$ $8.8 \mathrm{mg} / \mathrm{dL}$ after $12 \mathrm{wk})$.

Results for gene expression at baseline and $12 \mathrm{wk}$ are indicated in Figure 1 for the EGG and the SUB groups. HMG$\mathrm{CoA}$ reductase gene expression was down-regulated by

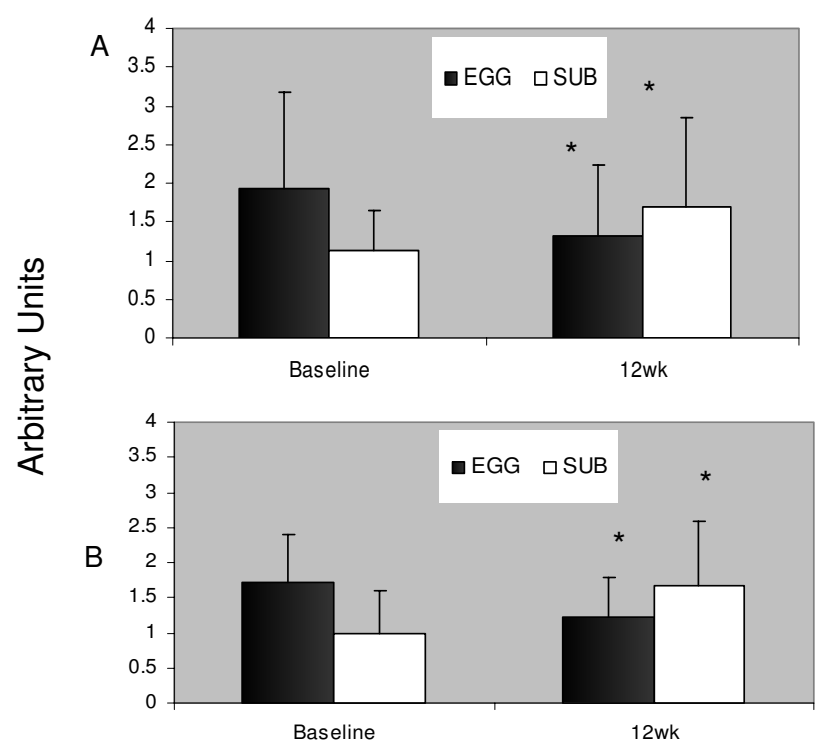

\section{Figure I}

HMG-CoA reductase mRNA abundance in mononuclear cells isolated from subjects from the EGG $(n=14)$ and SUB $(n=I I)$ groups (Panel A); LDL receptor mRNA abundance in mononuclear cells isolated from subjects from the EGG ( $n$ $=15)$ and SUB $(n=13)$ groups. Values represent arbitrary unit presented as means \pm standard deviation. $*$ indicates significantly different from baseline.
$31 \%$ and the LDL-r by $29 \%$ in the EGG group $(\mathrm{P}<0.05)$ while in the SUB group the expression of both genes was up-regulated by 53 and $66 \%$ respectively $(\mathrm{P}<0.05)$.

\section{Discussion}

Mononuclear cells were used as a surrogate to reflect hepatic cholesterol homeostasis in response to a cholesterol challenge. The present study suggests the involvement of dietary cholesterol in gene regulation. In the EGG group there was a $298 \%$ increase in dietary cholesterol intake compared to the SUB group. The LDL-C did not change during the intervention for both the EGG and SUB groups. The increase in dietary cholesterol on the EGG group might have contributed to the increase in intracellular cholesterol and significantly down regulate the mRNA expression of LDL-r and HMG-CoA reductase. These findings are supported by Meddings et al.,[19] and Lin et al., [20]. High dietary cholesterol generally elevates serum LDL-C, which might result in an increase in intracellular cholesterol via cholesterol uptake. The failure to observe the increase in plasma LDL cholesterol in the present study can be explained by the weight reduction, which might have prevented an increase accumulation of LDL-C. Studies in guinea pigs have shown that dietary cholesterol increases hepatic tissue cholesterol [21], which could possibly explain the down regulation of HMG-CoA reductase in the current work.

Studies using cultured cells [10], showed that a reduction in intracellular cholesterol levels resulted in a dual response: 1 . an increase in the production of mRNA for HMG-CoA reductase to synthesize more cholesterol for the depleted cell and 2. an increase in the amount of mRNA for the LDL-r in order to increase exogenous cholesterol uptake.

A previous study in our lab in pre-menopausal women has shown that weight loss results in the increase of LDL$r$ mRNA abundance [22]. A study using the fat Zucker rat [23], showed that these rats had reduced expression of hepatic LDL-r as compared to lean ones. A dietary cholesterol challenge had a suppressive outcome on hepatic LDL-r in both the Zucker and control rats. How does obesity influence cholesterol status? In obesity where there is no cholesterol challenge, the tissue might have a sufficient supply of cholesterol as a result of stored cellular lipids, and hence, the down regulation of the mechanism involved in the increase of cellular cholesterol synthesis and uptake. With weight loss where most of the weight reduced is from adipose tissues, there is a depletion of stored and available cellular cholesterol, and therefore, the mechanism to increase cellular cholesterol is up-regulated. This study supports these findings since the SUB group significantly increased LDL-r mRNA as a result of weight loss. Additionally, the findings for the EGG group 
suggests that the presence of a cholesterol challenge on a weight loss overrides the effect of LDL-r mRNA expression during weight loss, and this results in down regulation of the LDL receptor.

\section{Abbreviations}

CRD: carbohydrate restricted diets; HDL-C: HDL cholesterol; HMG-CoA: 3-hydroxy-3methyl glutaryl Coenzyme A; LDL-C: LDL cholesterol; LDL-r: LDL receptor; TC: total cholesterol.

\section{Competing interests}

The author(s) declare that they have no competing interests.

\section{Authors' contributions}

All authors read and approved the final manuscript. GM did the assays, wrote the manuscript and participated in the interpretation of data; MT: assisted in data collection, interpretation and critical evaluation of manuscript; MM: developed the molecular techniques and assisted in data interpretation; JSV participated with experimental design and critical evaluation of the data and MLF designed the experiment, evaluated the results, interpreted the data and participated in manuscript preparation.

\section{Acknowledgements}

Supported an award from the American Egg Board/Egg Nutrition Center to MLF.

\section{References}

I. Cannon B, Lewis A, Metze J, Thiagarajan V, Vaughn MW, Somerharju P, Virtanen J, Huang J, Cheng KH: Cholesterol Supports Headgroup Superlattice Domain Formation in Fluid Phospholipid/ Cholesterol Bilayers. J Phys Chem B 2006, I I O( I 2):6339-6350.

2. Pandit SA, Bostick D, Berkowitz ML: Complexation of Phosphatidylcholine Lipids with Cholesterol. Biophys J 2004, 86(3): I345-1356.

3. Anderson RGW, Jacobson K: A Role for Lipid Shells in Targeting Proteins to Caveolae, Rafts, and Other Lipid Domains. Science 2002, 296(5574): | $82|-| 825$.

4. Maxfield FR, Tabas I: Role of cholesterol and lipid organization in disease. Nature 2005, 438(7068):6 I2-62 I

5. Simons K, Ikonen E: How Cells Handle Cholesterol. Science 2000, 290(5497): |72|-I726.

6. Preiss B: Regulation of HMG-CoA reductase. New York, Academic Press; I 985:330 pp.

7. Goldstein JL, Brown MS: Progress in understanding the LDL receptor and HMG-CoA reductase, two membrane proteins that regulate the plasma cholesterol. J Lipid Res 1984, 25(13): |450-|46I.

8. Rudling MJ, Reihner E, Einarsson K, Ewerth S, Angelin B: Low Density Lipoprotein Receptor-Binding Activity in Human Tissues: Quantitative Importance of Hepatic Receptors and Evidence for Regulation of Their Expression in vivo. Proceedings of the National Academy of Sciences 1990, 87(9):3469-3473.

9. Spady DK, Turley SD, Dietschy JM: Rates of low density lipoprotein uptake and cholesterol synthesis are regulated independently in the liver. J Lipid Res 1985, 26(4):465-472.

10. Brown MS Goldstein, JL.: A receptor-mediated pathway for cholesterol homeostasis. Science 1986, 232(4746):34-47.

II. Cuthbert JA, Russell DW, Lipsky PE: Regulation of low density lipoprotein receptor gene expression in human lymphocytes. J Biol Chem I989, 264(2): I298-I304.
12. Goldstein LJ, Brown SM: The Low-Density Lipoprotein Pathway and its Relation to Atherosclerosis. Annual Review of Biochemistry 1977, 46(I):897-930.

13. Pocathikorn A, Taylor RR, James I, Mamotte CDS: LDL-Receptor mRNA Expression in Men Is Downregulated within an Hour of an Acute Fat Load and Is Influenced by Genetic Polymorphism. J Nutr 2007, I37(9):2062-2067.

14. Wood RJ Fernandez, ML., Sharman, MJ., Silvestre, R., Greene, CM., Zern, TL., Shrestha, S., Judelson, DA., Gomez, AL., Kraemer, W]., Volek, JS.: Effects of a carbohydrate-restricted diet with and without supplemental soluble fiber on plasma low-density lipoprotein cholesterol and other clinical markers of cardiovascular risk. Metabolism 2007, 56:58-67.

15. Böyum A: Isolation of mononuclear cells and granulocytes from human blood. Isolation of monuclear cells by one centrifugation, and of granulocytes by combining centrifugation and sedimentation at I g. Scand J Clin Lab Invest Suppl I968, 97:77-89.

16. Chomczynski P, Sacchi N: Single-step method of RNA isolation by acid guanidinium thiocyanate-phenol-chloroform extraction. Analytical Biochemistry 1987, I 62(I): I56-I59.

17. Barber RD, Harmer DW, Coleman RA, Clark BJ: GAPDH as a housekeeping gene: analysis of GAPDH mRNA expression in a panel of $\mathbf{7 2}$ human tissues. Physiol Genomics 2005, 2 I (3):389-395.

18. Wood RJ, Volek JS, Davis SR, Dell'Ova C, Fernandez ML: Effects of a carbohydrate-restricted diet on emerging plasma markers for cardiovascular disease. Nutr Metab (London) 2006, 3( I 9):.

19. Meddings JB Spady, DK., Dietschy, JM.: Kinetic characteristics and mechanisms of regulation of receptor-dependent and receptor-independent LDL transport in the liver of different animal species and humans. Am Heart J 1987, I I 3:475-48I.

20. Lin ECK, Fernandez ML, McNamara DJ: Dietary Fat Type and Cholesterol Quantity Interact to Affect Cholesterol Metabolism in Guinea Pigs. J Nutr 1992, I 22( I 0):2019-2029.

21. Torres-Gonzalez M, Shrestha S, Sharman M, Freake HC, Volek JS, Fernandez ML: Carbohydrate Restriction Alters Hepatic Cholesterol Metabolism in Guinea Pigs Fed a Hypercholesterolemic Diet. J Nutr 2007, I37( I 0):2219-2223.

22. Patalay M, Lofgren IE, Freake HC, Koo SI, Fernandez ML: The Lowering of Plasma Lipids following a Weight Reduction Program Is Related to Increased Expression of the LDL Receptor and Lipoprotein Lipase. J Nutr 2005, I35(4):735-739.

23. Liao W, Angelin B, Rudling M: Lipoprotein Metabolism in the Fat Zucker Rat: Reduced Basal Expression but Normal Regulation of Hepatic Low Density Lipoprotein Receptors. Endocrinology 1997, I38(8):3276-3282.

Publish with Bio Med Central and every scientist can read your work free of charge

"BioMed Central will be the most significant development for disseminating the results of biomedical research in our lifetime. "

Sir Paul Nurse, Cancer Research UK

Your research papers will be:

- available free of charge to the entire biomedical community

- peer reviewed and published immediately upon acceptance

- cited in PubMed and archived on PubMed Central

- yours - you keep the copyright
BiolMedcentral 